\title{
KEBERSIHAN GIGI DAN MULUT SISWA KELAS IV DAN V SD GMIM I AERTEMBAGA KOTA BITUNG
}

\author{
Jean Henry Raule \\ Jurusan Keperawatan Gigi Poltekkes Kemenkes Manado \\ Email : jeanhenryr@yahoo.com
}

\begin{abstract}
ABSTRAK
Pendahuluan : Pengetahuan merupakan hasil "tahu" dan ini terjadi setelah orang melakukan pengindraan terhadap suatu objek tertentu. Mengukur kebersihan gigi dan mulut menggunakan Oral Hygine Index Simplified dari Green Vermilion OHI-S diperoleh dengan cara menjumlahkan debris indeks dan kalkulus indeks. Penelitian ini bertujuan untuk mendapatkan informasi kebersihan gigi dan mulut siswa SD GMIM 1 Aertembaga Kota Bitung. Metode : Metode penelitian ini adalah metode Deskriptif dengan data sekunder untuk menggambarkan indeks kebersihan gigi dan mulut siswa kelas IV dan V SD GMIM 1 Aertembaga. Waktu penelitian pada bulan Juli 2019 yang bertempat di SD GMIM 1 Aertembaga Kota Bitung. Sampel yang digunakan yaitu 30 siswa sebagai responden, yang di tetapkan secara Purporsive sampling dengan menggunakan kriteria inklusi. Instrument penelitian yang digunakan adalah Format $O H I-S$ dan alat diagnotik set untuk pemeriksaan $O H I-S$. Data yang diperoleh ditabulasi dan disajikan dalam bentuk tabel distribusi persentase kemudian di deskripsikan. Hasil : Hasil penelitian responden dengan $O H I-S$ kriteria sedang berjumlah 26 responden ( 86,6\%) dan kriteria $O H I-S$ buruk berjumlah 3 responden $(10 \%)$, sedangkan kriteria $O H I-S$ baik berjumlah 1 responden $(3,33 \%)$. OHI-S berdasarkan Jenis Kelamin Laki-laki 18 ( 60\%),Perempuan 8( 26\%), dan OHI-S siswa berdasarkan Usia: Usia 10 tahun 17 ( 56\%) dan Usia 11 Tahun 9 ( 20\%) responden . Kesimpulan: OHI-S anak kelas IV dan V SD GMIM 1 Aertembaga adalah kategori Sedang.
\end{abstract}

\section{Kata kunci : Indeks OHI-S, Siswa Kelas IV dan V}

\begin{abstract}
Introduction : Knowledge is one of the domains of human behavior. Knowledge is the result of "knowing" and this happens after people perceive a particular object. Measuring oral and dental hygiene using the Oral Hygine Index Simplified from Green Vermilion OHI-S is obtained by adding up index debris and index calculus. This study aims to obtain dental and oral hygiene information for elementary students of GMIM 1 Aertembaga in Bitung City. Methods: This research method is a descriptive method with secondary data to describe the index of dental and oral hygiene of students in grade IV and V of SD GMIM 1 Aertembaga. The time of the study was in July 2019 which was held at SD GMIM 1 Aertembaga in Bitung City. The sample used was 30 students as respondents, which were determined by purposive sampling using inclusion criteria. The research instrument used was the OHI-S format and diagnostic set for OHI-S examination. The data obtained is tabulated and presented in the form of a percentage distribution table and then described. Result : The results of the study of respondents with moderate criteria for OHI-S amounted to 26 respondents $(86.6 \%)$ and poor OHI-S criteria amounted to 3 respondents $(10 \%)$, while good
\end{abstract}


OHI-S criteria amounted to 1 respondent (3.33\%). OHI-S based on Gender Male 18 (60\%), Female 8 (26\%), and OHI-S students based on Age: Age 10 years 17 (56\%) and Age 11 Years 9 (20\%) respondents. Conclusion: OHI-S grade IV and V students of SD GMIM 1 Aertembaga are in the Medium category.

Keywords: OHI-S Index, Class IV and V

\section{PENDAHULUAN}

Salah satu upaya untuk menentukan keadaan kesehatan gigi dan mulut seseorang,adalah dengan mengukur kebersihan gigi dan mulut orang tersebut. Pada umumnya untuk mengukur kebersihan gigi dan mulut digunakan suatu indeks. Indeks adalah suatu angka yang menunjukan keadaan klinis yang didapat pada waktu dilakukan pemeriksaan, dengan cara mengukur luas dari permukaan gigi yang ditutupi oleh plak maupun kalkulus, dengan demikian angka yang diperoleh berdasarkan penilaian yang obyektif. ${ }^{1}$

Hasil Riset Kesehatan Dasar RISKESDAS (2013) prevalensi masalah gigi dan mulut penduduk Indonesia mencapai 25,9\%, dan RISKESDAS (2018) terjadi peningkatan prevalensi masalah gigi dan mulut penduduk Indonesia menjadi $57,6 \%$ sedangkan prevalensi masalah gigi dan mulut untuk provinsi Sulawesi Utara pada RISKESDAS (2013) yaitu 31,6\% dan pada RISKESDAS (2018) terjadi peningkatan prevalensi masalah gigi dan mulut mencapai 55,5\%. ${ }^{2,3}$

Kebersihan gigi dan mulut adalah bebasnya gigi dan mulut dari sisa makanan dan kuman-kuman yang merusak gigi. Deposit atau lapisan yang menumpuk pada permukaan gigi dapat dikelompokkan menjadi acquired pellicle, material alba, debris makanan, plak gigi, dental stain dan kalkulus. ${ }^{1}$
Pengukuran kebersihan gigi dan

mulut dalam Putri dkk, 2010 menggunakan Oral Hygiene Index Simplified menurut Green and vermillion OHI-S diperoleh dengan cara menjumlahkan debris indeks dan kalkulus indeks. Permukaan yang diperiksa adalah permukaan gigi yang jelas terlihat dalam mulut, yaitu permukaan klinis bukan permukaan anatomis. Gigi-gigi yang dipilih sebagai gigi indeks beserta permukaan indeks yang dianggap mewakili tiap segmen adalah pada gigi 16 pada permukaan bukal, gigi 11 pada permukaan labial, gigi 26 pada permukaan bukal, gigi 36 pada permukaan lingual, gigi 31 pada permukaan labial, gigi 46 pada permukaan lingual. Jika gigi indeks pada suatu segmen tidak ada, lakukan penggantian gigi tersebut dengan ketentuan sebagai berikut.

1. Jika gigi M1 rahang atas atau bawah tidak ada, penilaian dilakukan pada gigi M2, jika gigi M1 dan M2 tidak ada penilaian dilakukan pada M3 akan tetapi jika gigi M1,M2, dan M3 tidak ada maka tidak ada penilaian untuk segmen tersebut.

2. Jika gigi I1 kanan atas tidak ada, dapat diganti oleh gigi I1kiri rahang atas dan jika gigi I1 kiri bawah tidak ada, dapat diganti oleh gigi I1 kanan rahang bawah, akan tetapi jika gigi I1 kiri dan I1 kanan tidak ada, maka tidak ada penilaian untuk segmen tersebut. 
JIGIM (Jurnal Ilmiah Gigi \& Mulut)

Untuk mempermudah penilaian, sebelum melakukan penilaian debris, kita dapat membagi permukaan gigi yang akan dinilai dengan garis khayal menjadi 3 bagian sama besar/ luasnya secara horizontal. $^{1}$

1. Mencatat Skor Debris.

Oral debris adalah bahan lunak di permukaan gigi yang dapat merupakan plak, material alba, dan food debris. Kriteria skor debris terdapat pada tabel berikut.

Tabel 1. Kriteria Penilaian Debris.

\begin{tabular}{cl}
\hline Skor & Kondisi \\
\hline 0 & Tidak ada debris atau stain \\
1 & $\begin{array}{l}\text { Plak menutup tidak lebih dari } 1 / 3 \\
\text { permukaan servikal, atau terdapat } \\
\text { stain ekstrinsik di permukaan yang } \\
\text { diperiksa }\end{array}$ \\
2 & $\begin{array}{l}\text { Plak menutup lebih dari 1/3 tapi } \\
\text { kurang dari 2/3 permukaan yang } \\
\text { diperiksa } \\
\text { Plak menutup lebih dari 2/3 } \\
\text { permukaan yang diperiksa }\end{array}$ \\
\hline
\end{tabular}

2. Mencatat Skor Kalkulus

Kalkulus adalah deposit keras yang terjadi akibat pengendapan garam-garam anorganik yang komposisi utamanya adalah kalsium karbonat dan kalsium fosfat yang bercampur dengan debris, mikroorganisme, dan sel-sel epitel deskuamasi. Kriteria skor kalkulus terdapat pada tabel berikut.

Tabel 2. Kriteria kalkulus

\begin{tabular}{cl}
\hline Skor & Kondisi \\
\hline 0 & Tidak ada kalkulus \\
1 & Kalkulus supragingiva menutup tidak \\
& lebih dari 1/3 permukaan servikal yang \\
& diperiksa \\
2 & Kalkulus supragingiva menutupi lebih \\
& dari 1/3 tapi kurang dari $2 / 3$ permukaan \\
& yang diperiksa, atau ada bercak kalkulus \\
& subgingiva di sekeliling servikal gigi \\
3 & Kalkulus supragingiva menutup lebih \\
& dari 2/3 permukaan atau ada kalkulus \\
subgingiva yang berada disekeliling \\
servikal gigi
\end{tabular}

Raule JH, Kebersihan Gigi dan Mulut

3. Menentukan kriteria debris indeks, kalkulus indeks dan OHI-S

Menurut Greene dan Vermillion, kriteria penilaian debris dan kalkulus sama, yaitu mengikuti ketentuan sebagai berikut. Baik nilainya antara 0-0,6, sedang nilainya antara 0,7-1,8, bukur nilainya antara 1,93,0. Sedangkan OHI-S mempunyai kriteria tersendiri, yaitu mengikuti ketentuan sebagai berikut. Baik nilainya antara 0,01,2 , sedang nilainya antara 1,3-3,0, buruk nilainya antara $3,1-6,0 .{ }^{1}$

Penelitian yang dilakukan Mawuntu dkk, (2015) mengenai status kebersihan mulut pada siswa sekolah dasar di kawangkoan dengan jumlah sampel 65 siswa, dan hasil penelitian memperlihatkan Oral Hygiene Index Simplified (OHI-S) sebesar 1,5 dengan kriteria sedang. ${ }^{4}$

Proses Pemeriksaan kebersihan gigi dan mulut siswa pada saat penjajakan dan penenelitian di lakukan oleh petugas perawat gigi puskesmas. Pada pemeriksaan awal secara acak saat survey pada 5 orang siswa yang terdaftar di SD GMIM I Aertembaga Kecamatan Aertembaga diperoleh indeks OHI-S rata-rata debris indeks sebesar 3,2 dengan kriteria Buruk. Hal ini memperlihatkan kriteria penilaian OHI-S melebihi standar yang ditetapkan oleh Green and Vermilion, yaitu 0-0,6 berkategori (baik). Mencermati permasalahan tersebut di atas maka peneliti tertarik untuk mengetahui lebih lanjut lagi bagaimana gambaran Karies gigi pada siswa kelas IV dan V SD GMIM 1 Aertembaga Kecamatan Aertembaga Kota Bitung.

Tujuan penelitian ini

Mendeskripsikan Kebersihan gigi dan Mulut berdasarkan umur dan jenis kelamin siswa kelas IV dan V SD GMIM 
JIGIM (Jurnal Ilmiah Gigi \& Mulut)

1 Aertembaga Kecamatan Aertembaga Kota Bitung

\section{METODE}

Jenis penelitian ini adalah penelitian Deskriptif dengan data sekunder untuk menggambarkan indeks kebersihan gigi dan mulut siswa kelas IV dan V SD GMIM 1 Aertembaga.

Waktu penelitian pada bulan Juli 2019 yang bertempat di SD GMIM 1 Aertembaga Kota Bitung.

Sampel yang digunakan yaitu 30 siswa sebagai responden, yang di tetapkan secara Purporsive sampling dengan menggunakan kriteria inklusi.

Instrument penelitian yang digunakan adalah Format $O H I-S$ dan alat diagnotik set untuk pemeriksaan $O H I-S$. Data yang diperoleh ditabulasi dan disajikan dalam bentuk tabel distribusi persentase kemudian di deskripsikan

\section{HASIL}

Penelitian ini dilakukan di Sekolah

Dasar GMIM 1Aertembaga Kecamatan Aertembaga Kota Bitung, yang didirikan sejak tahun 1976 oleh Pemerintahan Kota Bitung diatas tanah seluas 300 meter persegi yang terletak di Kelurahan Aertembaga kecamatan Aertembaga dengan batas-batas geografis sebagai berikut : Sebelah Utara ,Sebelah Timur dan Barat berbatasan dengan Rumah warga Kelurahan Aertembaga ,Sebelah Selatan Jalan Raya Samuel Languyu.

Sekolah Dasar GMIM 1 Aertembaga ini memilki 1 ruangan guru ,1 ruang kepala sekolah, 1 ruangan UKS dan 8 ruangan kelas. Jumlah seluruh siswa di Sekolah Dasar GMIM 1 Aertembaga ini
Raule JH, Kebersihan Gigi dan Mulut

sebanyak 208 orang yang terdiri dari kelas I :40 orang, kelas II : 27 orang, kelas III :36 orang, kelas IV: 17 orang, kelas V: 13 orang dan kelas VI: 36 orang dan semuanya merupakan siswa yang sedang menuntut ilmu di Sekolah Dasar GMIM 1Aertembaga.

1. Distribusi Responden Menurut Jenis Kelamin

Distribusi responden menurut jenis kelamin dapat dilihat pada tabel di bawah ini :

Tabel 3. Distribusi Responden Menurut Jenis Kelamin

\begin{tabular}{ccc}
\hline Umur & Jumlah & $(\boldsymbol{\%})$ \\
\hline Laki-laki & 18 & 0,6 \\
Perempuan & 12 & 0,4 \\
\hline Total & 30 & 100 \\
\hline
\end{tabular}

2. Distribusi responden menurut kelompok umur dapat dilihat pada tabel di bawah ini :

Tabel 4. Distribusi Responden Menurut Umur

\begin{tabular}{ccc}
\hline $\begin{array}{c}\text { Kelompok } \\
\text { Umur }\end{array}$ & Jumlah & $(\%)$ \\
\hline 10 Tahun & 19 & 63.3 \\
11 Tahun & 11 & 36.7 \\
\hline Total & 30 & 100 \\
\hline
\end{tabular}

3. Distribusi Indeks Kebersihan Gigi dan Mulut Responden Menurut Kriteria OHI-S

Distribusi kebersihan gigi dan mulut responden berdasarkan kriteria OHI-S dapat dilihat pada tabel di bawah : 
JIGIM (Jurnal Ilmiah Gigi \& Mulut)

\section{Tabel 5. Distribusi OHI-S Responden berdasarkan Kriteria OHI-S}

\begin{tabular}{ccc}
\hline $\begin{array}{c}\text { Kriteria } \\
\text { OHI-S }\end{array}$ & Jumlah & $\begin{array}{c}\text { Persentase } \\
(\%)\end{array}$ \\
\hline Baik & 1 & 3.33 \\
Sedang & 26 & 86.6 \\
Buruk & 3 & 10 \\
\hline Total & 30 & 100 \\
\hline
\end{tabular}

4. Distribusi responden menurut umur terhadap indeks OHI-S

Tabel 6. Distribusi responden menurut umur terhadap indeks OHI-S

\begin{tabular}{ccc}
\hline Kriteria OHI-S & Jumlah & $\begin{array}{c}\text { Persentase } \\
(\boldsymbol{\%})\end{array}$ \\
\hline Baik & 1 & 3.33 \\
Sedang & 26 & 86.6 \\
Buruk & 3 & 10 \\
\hline Total & 30 & 100 \\
\hline
\end{tabular}

\section{PEMBAHASAN}

Banyak hal sederhana yang perlu di lakukan untuk mendapatkan gigi yang sehat diantaranya menyikat gigi, pola makan yang sehat dan mengunjungi puskesmas, dokter gigi, rumah sakit atau balai pengobatan gigi setiap enam bulan sekali atau satu tahun dua kali. Jika hal-hal ini dilakukan rutin maka gigi dan mulut akan terbebas dari sis-sisa makanan sehingga kebersihan mulut dapat tercapai. Menurut Putri dkk,2010 Kebersihan gigi dan mulut adalah bebasnya gigi dan mulut dari sisa makanan dan kuman-kuman yang merusak gigi. ${ }^{1}$

Mengukur kebersihan gigi dan mulut merupakan upaya untuk menentukan keadaan kebersihan gigi seseorang . untuk mengukur kebersihan
Raule JH, Kebersihan Gigi dan Mulut

gigi dan mulut digunakan suatu indeks. Indeks adalah suatu angka yang menunjukan keadaan klinis yang didapat pada waktu dilakukan pemeriksaan, dengan cara mengukur dari luas permukaan gigi yang ditutupi oleh plak maupun kalkulus, dengan demikian angka yang diperoleh berdasarkan penilaian yang objektif. $^{1}$

Hasil penelitian pada siswa kelas IV dan V siswa SD GMIM 1 Aertembaga Kecamatan Aertembaga Kota Bitung, diperoleh indeks OHI-S rata-rata 3,2 dimana indeks ini termasuk kriteria buruk. Kriteria ini mengacu pada konsep Green and Vermilion yang di kutip oleh Putri (2010) mengenai kriteria/kategori OHI-S sebagai berikut : Baik dengan nilai Indeks 0,0 - 1,2 Sedang 1,3 - 3,0 dan Buruk 3,1-6,0. Masih rendahnya status kebersihan gigi dan mulut responden ,menunjukkan bahwa siswa belum bisa menjaga kebersihan gigi dan mulutnya. sementara perilaku dalam hal menjaga kebersihan gigi dan mulut merupakan perilaku yang di harapkan untuk dilakukan siswa.

Faktor Perilaku Manusia dalam konteks ini Perilaku kesehatan memiliki andil besar dan berperan penting dalam mempengaruhi status kesehatan gigi dan mulut yang dapat di lakukan dengan meningkatkan pengetahuan, sikap dan tindakan kesehatan, sebagai pendorong terlaksananya sebuah perilaku yang sadar akan kesehatan gigi dan mulut,dengan harapan semakin meningkatnya pengetahuan akan kesehatan maka akan semakin baik kesadaran yang memimicu terlaksananya perilaku kesehatan, dalam hal ini perilaku kesehatan gigi dan mulut. ${ }^{5}$

Menurut Astuti Rahmawati (2006), semakin baik perilaku membersihkan gigi, maka semakin baik tingkat kebersihan gigi 
dan mulut, sebaliknya semakin jelek perilaku membersihkan gigi, maka semakin jelek pula tingkat kebersihan gigi dan mulutnya. ${ }^{6}$ Menurut Mawuntu, dkk (2015), kesadaran terhadap kebersihan mulut pada anak-anak sangat rendah yang diakibatkan karena kurangnya pendidikan dan kemampuan anak-anak dalam menjaga kebersihan gigi dan mulut umumnya pada anak usia sekolah antara usia 6-12 tahun kurang mengetahui dan mengerti tentang cara memelihara kebersihan mulut. Jika kondisi ini di biarkan akan mengakibatkan penurunan kualitas kebersihan gigi dan mulut. ${ }^{4}$

Rendahnya kualitas kebersihan gigi dan mulut tidak hanya di pengaruhi oleh faktor perilaku tetapi ada faktor lain yang ikut mempengaruhi kebersihan gig dan mulut adalah faktor jenis kelamin. Berdasarkan data hasil penelitian (Tabel.5), menunjukan bahwa sebagian besar siswa laki-laki memiliki kebersihan gigi dan mulut pada kriteria OHI-S sedang $18(60 \%)$,dibandingkan dengan perempuan 8 (26\%). Kondisi demikian ini dapat disebabkan karena perempuan memiliki kecenderungan untuk lebih menjaga penampilannya termasuk kebersihan gigi dan mulutnya di bandingkan laki laki ,selain itu anak laki-laki memiliki kecenderungan aktivitas bermain yang tinggi sehingga sering mengabaikan atau kurang memperhatikan kebersihan mulutnya. Selain intensitas bermain yang tinggi, mereka gemar makan atau mengkonsumsi makanan berkarbohidrat karena rasanya yang manis dan enak, apalagi jika makanan-jajanan tersebut sangat mudah mereka dapatkan karena tersedia di di warung-warung di lingkungan dimana mereka tinggal yang menjual berbagai jenis makanan manis dan mudah melekat. ${ }^{3}$
Selain faktor Perilaku dan faktor jenis kelamin responden, terdapat faktor Usia yang ikut mempengaruhi kebersihan gigi dan mulut, (Tabel 6) yang menunjukan bahwa responden yang berumur 10 tahun dengan kriteria OHI-S sedang yaitu 17 (56\%), responden di bandingkan dengan umur 11 tahun, 8 (26 $\%)$ responden. Tabel 6 ,umur responden berada pada usia antara 10 dan 11 tahun dengan kategori OHI-S adalah Sedang. Kondisi ini di sebabkan karena pada fase usia seperti ini ( usia 10 dan 11 tahun) merupakan usia masa menanjak dari masaanak anak ke masa remaja. selain bertambah umur, pada fase usia seperti ini anak berusaha untuk memahami sesuatu dan berusaha untuk menjadi sesuatu sehingga bertambah juga pengetahuan mereka tentang sesuatu hal, termasuk memahami tentang pengetahuan kesehatan. Menurut Sirait, dkk, (2009) selain bertambahnya umur, akan bertambah juga pengetahuan anak sehingga akan semakin luas pengetahuannya termasuk pengetahuan tentang kebersihan gigi dan mulut yang akhirnya mereka dapat mengetahui juga cara untuk menjaga kebersihan gigi dan mulutnya dengan baik pula. ${ }^{7}$

\section{KESIMPULAN}

Gambaran Indeks Kebersihan Gigi dan Mulut Siswa Kelas IV dan V SD GMIM 1 Aertembaga Kecamatan Aertembaga Kota Bitung, di simpulkan :

1. $26(86,6 \%)$ responden siswa kelas IV dan $\mathrm{V}$ termasuk pada kriteria OHI-S Sedang, 3 (10\%) responden dengan kriteria OHI-S Buruk dan 
1(3,33\%) responden kriteria OHI-S Baik.

2. 18 (60\%), responden Laki-laki termasuk pada kriteria OHI-S Sedang, dan Perempuan 8 (26\%) responden

3. $17(56 \%)$ responden berusia 10 tahun dan $9(20 \%)$ responden berusia 11 Tahun.

\section{SARAN}

Untuk semua Siswa SD GMIM 1 Aertembaga Kecamatan Aertembaga Kota Bitung, supaya lebih memperbaiki sikap dalam menjaga kesehatan gigi dan mulut dengan cara membiasakan diri dengan halhal yang baik dengan cara :

a. Menyikat gigi secara teratur dan pada waktu yang tepat, pagi setelah sarapan, siang sesudah makan siang, dan malam sebelum tidur.

b. Mengurangi dan jika peril hindari makanan yang manis lengket, seperti coklat dan permen, serta rajin mengkonsumsi buah-buahan berserat dan berair.

c. Kontrol ke poli gigi 6 bulan sekali atau 1 tahun dua kali.

d. Bertanyalah kepada petugas Kesehatan gigi jika ada hal hal yang kurang di mengerti

Bagi pihak sekolah tingkatkan koordinasi serta kerja sama dengan pihak Puskesmas yang terkait dengan kegiatan UKGS sehingga para siswa dapat rutin memeriksakan giginya di sekolah.

Bagi institusi pendidikan dan peneliti, adakan penelitian lanjutan terhadap variable yang lain dan libatkan populasi yang lebih luas untuk mendapatkan hasil yang lebih representative

\section{DAFTAR PUSTAKA}

1. Putri, H.M., Herijulianti, E., dan Nurjannah, N. (2011). Ilmu Pencegahan Penyakit Jaringan Keras dan Jaringan Pendukung. PT Buku Kedokteran EGC. Jakarta.

2. Kementerian Kesehatan RI., (2013). Riset Kesehatan Dasar, Badan Penelitian \& Pengembangan Tenaga Kesehatan Kemenkes. Laksana, Jakarta

3.

Riset Kesehatan Dasar, Badan Penelitian \& Pengembangan Tenaga Kesehatan Kemenkes. Laksana, Jakarta

4. Mawuntu M, Pangemanan DHC, Mintjelungan C,(2015). Gambaran Status Kebersihan Mulut Siswa SD Katolik St. Agustinus Kawangkoan. Jurnal e-GiGi (eG), Volume 3, Nomor 2, Juli-Desember 2015

5. Budiharto, (2008). Pengantar Ilmu Perilaku Kesehatan Dan Pendidikan Kesehatan Gigi. EGC. Jakarta

6. Astuti R. (2006). Hubungan perilaku membersihkan gigi terhadap tingkat kebersihan mulut siswa Sekolah Dasar Negeri di wilayah kerja Puskesmas Gladak Pakem kabupaten Jember: JKGI. 10(3): 19-14.

7. Sirait, R. U. (2009). Prevalensi Penyakit Mulut pada Anak Usia 12-15 Tahun di Desa Ujung Rambung Kecamatan Pantai Cermin Kabupaten Serdang Bedagai, Sumatera Utara Tahun 2009. Skripsi FKG US 